\title{
Life Span of Carbamylated Red Cells in Sickle Cell Anemia
}

\author{
Paul F. Milner and Samuel Charache \\ From the Department of Medicine, Johns Hopkins University School of \\ Medicine and Johns Hopkins Hospital, Baltimore, Maryland 21205
}

A B S T R A C T By using three isotopes of diisopropylphosphofluoridate $\left(\left[{ }^{3} \mathrm{H}\right]-,\left[{ }^{14} \mathrm{C}\right]-\right.$, and $\left.\left[{ }^{32} \mathrm{P}\right] \mathrm{DFP}\right)$ simultaneously, the life span of red cells from 20 patients with sickle cell anemia (Hb SS) has been studied after varying degrees of carbamylation in vitro with cyanate (NCO) and carbamyl phosphate (CP). The results are expressed in terms of the red cell mean life span (MLS).

The MLS of red cells in the patients studied averaged 15.2 \pm 6.3 (SD) days. After carbamylation the increase in red cell life span was linearly proportional to the concentration of cyanate used, so that at 0.01 , 0.02 , and $0.3 \mathrm{M} \mathrm{NCO}$ (approximately 1, 1.6, and 2 $\mathrm{mol} \mathrm{NCO} / \mathrm{mol} \mathrm{Hb}$ ) the average increase in MLS was 8.14 \pm 4.9 days, $14.7 \pm 4.1$ days, and $18.4 \pm 8.8$ days, respectively.

Analysis of survival curves and the results of an experiment using a population of $\mathrm{Hb} \mathrm{SS}$ cells separated by centrifugation indicated that carbamylation had a disproportionate effect on the survival of the youngest cells in the population. Improvement in MLS correlated with the reticulocyte count of the cells carbamylated. This finding is explained on the hypothesis that the life span of irreversibly sickled and other damaged cells is not improved by carbamylation but that carbamylation greatly improves the life span of the young, and as yet undamaged, cells. For this reason extracorporeal carbamylation is not favored as a form of therapy. At the level of carbamylation attainable by oral therapy, however, it would appear likely that only a modest increase in red cell life span will be achieved.

\section{INTRODUCTION}

In 1971 Cerami and Manning (1) reported that cyanate $(\mathrm{NCO})^{2}$ at a concentration of $0.01-0.10 \mathrm{M}$ in-

Received for publication 18 June 1973 and in revised form 14 August 1973.

${ }_{1}$ Abbreviations used in this paper: $\mathrm{CP}$, carbamyl phos- hibits the in vitro sickling of red cells from patients with sickle cell anemia ( $\mathrm{Hb} \mathrm{SS}$ ). In a subsequent publication, Gillette, Manning, and Cerami (2) reported that $\mathrm{Hb} \mathrm{SS}$ red cells, incubated in $0.05 \mathrm{M}$ sodium cyanate for $60-90 \mathrm{~min}$ at $37^{\circ} \mathrm{C}$, had an increased lifespan in vivo compared with a previous measurement of red cell life-span with ${ }^{51} \mathrm{Cr}$ in the same patient.

Cyanic acid, the active form of cyanate in solution, carbamylates the $\alpha-\mathrm{NH}_{2}$ groups of proteins.

$$
\mathrm{R}-\mathrm{NH}_{2}+\mathrm{HNCO} \rightarrow \mathrm{R}-\mathrm{NH}-\mathrm{CO}-\mathrm{NH}_{2} .
$$

In addition to this reaction, other reactive groups in protein may become carbamylated at higher cyanate concentrations (3). However, carbamylation of free $\alpha$ $\mathrm{NH}_{2}$ groups of hemoglobin is irreversible and occurs about 100 times more readily than other carbamylation reactions (4). At levels of carbamylation of 1-2 NCO residues per hemoglobin molecule the terminal $\mathrm{NH}_{2}$ groups are the main ones involved. Carbamylation of $\mathrm{N}$-terminal groups, of which there are four per molecule, raises the oxygen affinity (5), and it appears to be mainly for this reason that sickling is inhibited $(6,7)$.

Red cell life-span is variable in sickle cell anemia (8), and ${ }^{\circ} \mathrm{Cr}$ is not an ideal isotope as a red cell label because of variable elution $(9,10)$. Because of these difficulties in interpreting ${ }^{51} \mathrm{Cr}$ data, and because the survival of the treated and untreated cells was measured sequentially in the studies of Gillette et al. (2), we decided to study the effect of carbamylation on the survival of $\mathrm{Hb}$ SS cells in more detail, using diisopropylphosphofluoridate (DFP) to label the cells (11). DFP is available in three isotopic forms, ${ }^{8} \mathrm{H},{ }^{14} \mathrm{C}$, and ${ }^{2} \mathrm{P}$. By using all three isotopes we have been able to compare the survival of each patient's red cells subjected to varying degrees of carbamylation concurrently

phate; DFP, diisopropylphosphofluoridate; $\mathrm{Hb}$ SS, sickle cell anemia; MLS, mean life-span; NCO, cyanate.

The Journal of Clinical Investigation Volume 52 December 1973.3161-3171 
with the survival of his untreated cells. As it has been reported that carbamyl phosphate (CP) also inhibits sickling (12) and improves red cell survival (13), we also examined the effect of this reagent on the life span of Hb SS cells.

In the course of this investigation it appeared that the mean age of the $\mathrm{Hb} \mathrm{SS}$ red cells at the time of carbamylation may govern the effect of the drug. Results of an exploration of this phenomenon raise questions about the potential merits of intermittent extracorporeal carbamylation versus carbamylation by daily oral dosage as a means of therpy.

\section{METHODS}

Informed consent was obtained from 20 patients with proven sickle cell anemia. They were all in a relatively asymptomatic state at the time of these investigations, and none had been recently transfused.

Sodium cyanate was obtained from K \& K Laboratories, Inc., Plainview, N. Y. and was recrystallized from $60 \%$ ethanol at $50^{\circ} \mathrm{C}$ and stored at room temperature. Carbamyl phosphate was obtained as the dilithium salt from Sigma Chemical Co., St. Louis, Mo. and kept at $-70^{\circ} \mathrm{C}$ in a desiccator. Solutions of these salts were made up immediately before use; these were $0.15 \mathrm{M} \mathrm{NCO}$ and $0.12 \mathrm{M} \mathrm{CP}$. Isotopes of DFP, $\left(\mathrm{C}^{3} \mathrm{H}_{3}\right)_{2} \mathrm{CHO}_{2} \mathrm{P}(\mathrm{O}) \mathrm{F}$, referred to as $\left[{ }^{3} \mathrm{H}\right] \mathrm{DFP}$, and $\left({ }^{14} \mathrm{CH}_{3}\right)_{2} \mathrm{CHO}_{2} \mathrm{P}(\mathrm{O}) \mathrm{F}$, referred to as $\left[{ }^{14} \mathrm{C}\right]-$ DFP, were obtained from New England Nuclear Corp., Boston, Mass. $\left(\mathrm{CH}_{3}\right)_{2} \mathrm{CHO}_{2}{ }^{32} \mathrm{P}(\mathrm{O}) \mathrm{F}$, referred to as $\left.{ }^{32} \mathrm{P}\right]-$ DFP, and $\left[{ }^{14} \mathrm{C}\right] \mathrm{KNCO}$ were obtained from Amersham/ Searle Corp., Arlington Heights, Ill. $\left[{ }^{32} \mathrm{P}\right] \mathrm{DFP}$ was supplied as a sterile solution; the other forms of DFP and the $\mathrm{KNCO}$ were sterilized by passage through $0.22-\mu \mathrm{m}$ Millipore filters, Millipore Corp, Bedford, Mass. after addition of an isotonic salt solution.

Carbamylation and labeling procedure. $500 \mathrm{ml}$ of venous blood were collected into ACD formula A in plastic blood bags. After the venesection, one isotope of DFP was injected intravenously to label the circulating cells. The bag of blood was then centrifuged, the plasma was carefully removed and discarded, and the semipacked cells separated into two satellite bags so as to obtain roughly equal portions. These bags were then weighed, and calculated volumes of isotonic $\mathrm{NCO}$ or $\mathrm{CP}$ were added through $0.22-\mu \mathrm{m}$ Millipore filters so as to obtain concentrations of $0.01,0.02$, or $0.03 \mathrm{M}$ in the red cell mass, assuming complete permeability. Isotopes of DFP were also added in amounts described below. The blood was gently mixed and allowed to stand in a $37^{\circ} \mathrm{C}$ water bath for $2 \mathrm{~h}$ with occasional mixing. After incubation the blood was washed three times with sterile $\mathrm{NaCl}$ solution and reinjected into the patient through a blood-giving set.

The recommended methods for radioisotopic erythrocyte survival studies were followed (14). The radioactivity administered did not exceed $0.7 \mu \mathrm{Ci} / \mathrm{kg}$ body weight for $\left[{ }^{32} \mathrm{P}\right]$ DFP and $7 \mu \mathrm{Ci} / \mathrm{kg}$ for $\left[{ }^{3} \mathrm{H}\right] \mathrm{DFP}$. The dose of $\left[{ }^{14} \mathrm{C}\right]-$ DFP did not exceed $50 \mu \mathrm{Ci}$. Much of this radioactivity was removed in the washings when cells were labeled in vitro, so that the total radioactivity injected was much less. The specific activity of the DFP ${ }^{2}$ was such that the amount added to the blood did not exceed $100 \mu \mathrm{g} / 100 \mathrm{ml}$ of red

${ }^{2}\left[{ }^{3} \mathrm{H}\right] \mathrm{DFP}=5 \mu \mathrm{Ci} / \mu \mathrm{g} ; \quad\left[{ }^{14} \mathrm{C}\right] \mathrm{DFP}=6 \mu \mathrm{Ci} / \mu \mathrm{g} ; \quad\left[{ }^{32} \mathrm{P}\right]-$ $\mathrm{DFP}=0.2 \mu \mathrm{Ci} / \mu \mathrm{g}$. cells, and the total quantity injected did not exceed 20 $\mu \mathrm{g} / \mathrm{kg}$ body weight.

Blood samples were obtained, using EDTA as anticoagulant, from the 3rd or 4th day after injection of the labeled cells, for a period of 6-8 wk. The hematocrit and hemoglobin concentration were measured, and the cells were washed three times and then lysed with a few drops of Triton X100. The hemoglobin concentration of this lysate was recorded. For ${ }^{32} \mathrm{P}$ counting, $1 \mathrm{ml}$ of hemolysate was pipetted in triplicate onto $3.7-\mathrm{cm}$ diameter Whatman GF/A glass fiber paper circles stuck to $1 \frac{1}{2} \times \frac{1}{8}$ inch plain aluminum planchettes with Duco Cement. ${ }^{3}$ After the blood had dried, it was covered with a thin layer of a $1: 2$ dilution of Eukitt microscopy mounting medium in toluene. Planchettes were counted to $5 \%$ error in an end window Geiger-Müller system with an aluminum filter $(33.8 \mathrm{mg} /$ $\mathrm{cm}^{2}$ ) to screen out radiation from ${ }^{14} \mathrm{C}$ and ${ }^{8} \mathrm{H}$. To count ${ }^{3} \mathrm{H}$ and ${ }^{14} \mathrm{C}, 0.5 \mathrm{ml}$ of hemolysate was pipetted in triplicate onto suspended filter papers (Whatman no. 43, 5.5-cm circles). When it was dry, each paper was folded inside a fresh filter paper and compressed into pellets weighing approximately $300 \mathrm{mg}$. The pellets were then combusted in a Packard 305 Tricarb Sample Oxidizer. ${ }^{5}$ The ${ }^{8} \mathrm{H}_{2} \mathrm{O}$ condensate was collected into a vial to which Instagel ${ }^{5}$ scintillator was added, and the ${ }^{14} \mathrm{CO}_{2}$ was collected into ethanolamine which was then automatically rinsed into a vial with methanol and Permablend III ${ }^{5}$ scintillator. Both vials were then counted in a Beckman LS 133 liquid scintillation counter (Beckman Instruments, Fullerton, Calif.). Quenching, which was considerable in the ${ }^{14} \mathrm{C}$ samples, was calculated by means of an external standard. The counting efficiency averaged $26 \%$ for ${ }^{3} \mathrm{H}$ and $60 \%$ for ${ }^{14} \mathrm{C}$. When a sample containing only $\left[{ }^{32} \mathrm{P}\right] \mathrm{DFP}$ was combusted no radioactivity was found in either the ${ }^{14} \mathrm{C}$ or ${ }^{8} \mathrm{H}$ vials. All samples were counted in triplicate to $2 \%$ error, the results were expressed as disintegrations per minute per milliliter of blood (dpm), and correction for background was obtained by counting unlabeled blood processed and burned in a similar fashion. The separation of ${ }^{3} \mathrm{H}$ and ${ }^{14} \mathrm{C}$ was complete, but carry over from one sample to the next in the combustion process was about $2 \%$ and was slightly more for ${ }^{3} \mathrm{H}$ than for ${ }^{14} \mathrm{C}$. To minimize this source of error all the pellets from one red cell survival experiment were kept and combusted together, beginning with the weakest.

The dpm for different days were first plotted roughly on semilog paper. When a straight line was seen to fit the points, the regression of the log of the dpm on time was obtained by the method of least squares. The correlation ,coefficient of the line was usually better than 0.95 , and in many instances it was better than 0.98 . The $y$ intercept was used to calculate the extrapolated radioactivity at zero time so as to express the $\mathrm{dpm}$ for each day as a percentage.

Calculation of mean cell life span (MLS). Since the disappearance functions appeared to be exponentials, over the period of observation, the slope of the regression of the common logarithms of $\mathrm{dpm}$ on time, as provided by the least-squares fit, was used to derive the coefficient of random destruction, $k(14,15)$, according to the equation:

$$
N_{t} / N_{0}=e^{-k t} \text {, }
$$

where $N_{0}$ and $N_{t}$ are $\mathrm{dpm}$ at zero time and elapsed time

\footnotetext{
${ }^{3}$ E. I. du Pont de Nemours \& Co., Wilmington, Del.
}

4Distributed by Calibrated Instruments Inc., Ardsley, N. Y.

${ }^{5}$ Packard Instrument Co., Inc., Downers Grove, Ill. 

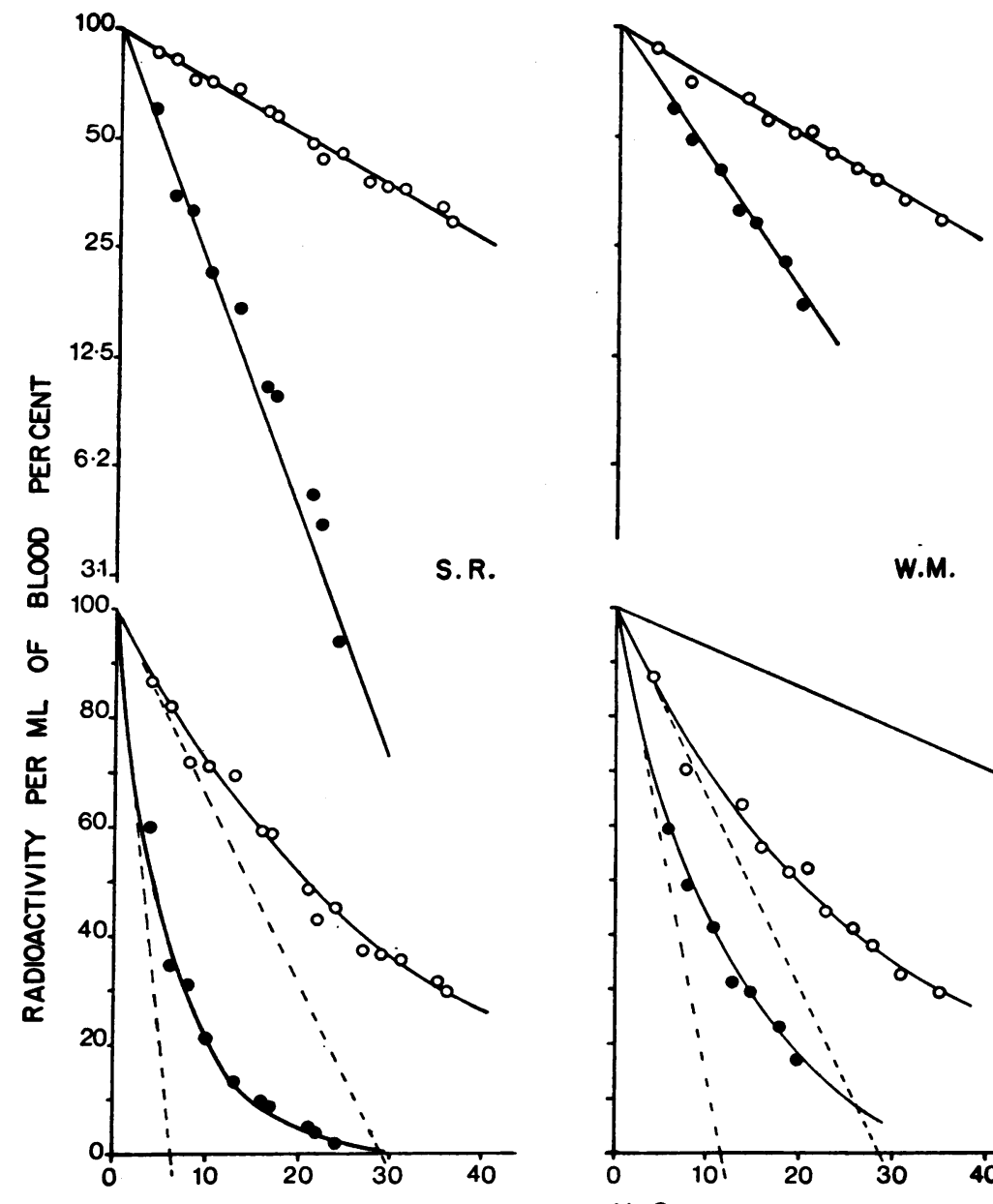

W.M.

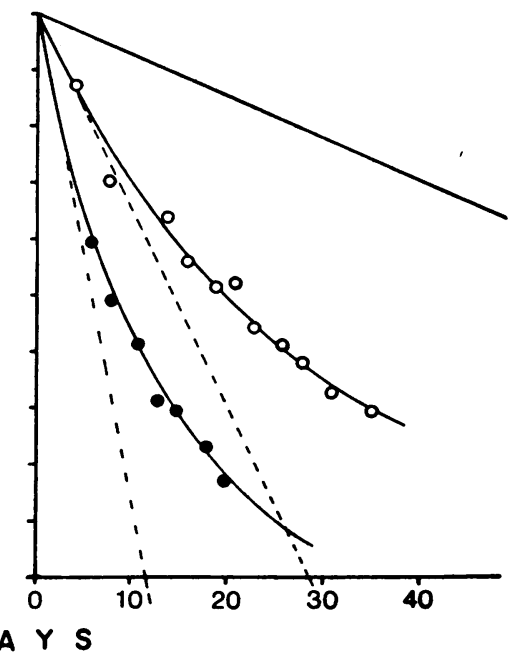

FIGURE 1 Isotope disappearance curves of carbamylated $\mathrm{Hb} \mathrm{SS}$ red cells labeled with $\left[{ }^{14} \mathrm{C}\right] \mathrm{DFP}$ (open circles), in two patients, compared with the disappearance of their uncarbamylated cells labeled with $\left[{ }^{3} \mathrm{H}\right] \mathrm{DFP}$ ( solid circles), shown at the top on a semilogarithmic plot and below on a linear ordinate. The broken lines on the linear plots have slopes equal to the rates of random destruction (see Methods). The point where these cut the time axis is defined as the mean life span (MLS) of the red cells. The continuous line represents the disappearance of DFP-labeled normal cells in a normal individual (16).

respectively, so that:

$$
\left(\log N_{t}-\log N_{0}\right) / t=-k \cdot M,
$$

where $M$ is the modulus of common logarithms $\left(\log _{10} e\right)$.

In each case, therefore, the slopes of the log regressions were divided by 0.4343 to obtain $k$. When the data, expressed as per cent of radioactivity on day zero, are plotted on linear coordinates, the tangent to the curve at zero time has a slope equal to $k$, expressed as a percentage destruction rate (Fig. 1). The point where this extrapolated tangent cuts the time axis is defined as the MLS (14-17). In the tables, MLS is calculated as $1 / k$. The mean life span is a result of all the factors affecting the survival of the cell (random loss and senescence) and is to be distinguished from the mean potential life span of cells which escape all destructive processes except senescence. The survival of a normal population of red cells labeled with
DFP, in a normal individual, is dscribed by a straight line on linear coordinates, which cuts the time axis at $124 \pm 7$ days (18). This is the MLS of normal cells, sometimes referred to as the potential life span of the red cell.

Measurement of the degree of carbamylation. In two separate experiments blood in ACD was incubated, as already described, in $0.01,0.02$, and $0.03 \mathrm{M} N C O$ or CP and, after the cells were washed, the degree of $N$-terminal carbamylation was determined in Peter Gillette's laboratory at The Rockefeller University, New York, by gas chromatography of valine hydantoin formed by treatment of globin with hot acid (19). The incorporation of $\left[{ }^{14} \mathrm{C}\right] \mathrm{KN}$.CO into hemoglobin was also measured during these incubations.

\section{RESULTS}

Brief hematological data on the patients are given in Table I, together with the mean life spans (MLS) of 
TABLE I

Sex, Age, Degree of Anemia and Red Cell Mean Life-Span of Hb SS Patients

\begin{tabular}{llcccccrc}
\hline Patient & Sex & Age & Hb & Hct. & Retics. & Hb F & \multicolumn{2}{c}{ MLS* } \\
\hline & & $y r$ & $g / 100 m l$ & $\%$ & $\%$ & $\%$ & days & $r$ \\
A. I. & F & 24 & 8.8 & 26 & 18.4 & 2.7 & 18.8 & $(0.975)$ \\
W. M. & M & 22 & 8.6 & 24 & 13.0 & 2.4 & 13.8 & $(0.992)$ \\
E. G. & M & 33 & 9.2 & 26 & 17.0 & 4.2 & 15.8 & $(0.991)$ \\
R. W. & M & 23 & 9.7 & 28 & 12.8 & 0.9 & 18.9 & $(0.984)$ \\
S. R. & M & 29 & 9.7 & 27 & 21.0 & 0.8 & 6.7 & $(0.982)$ \\
G. D. & F & 26 & 10.6 & 31 & 5.2 & 13.4 & 34.9 & $(0.993)$ \\
D. P. & F & 23 & 7.9 & 24 & 8.7 & 7.4 & 23.5 & $(0.951)$ \\
D. R. & M & 17 & 5.6 & 18 & 28.5 & 10.6 & 12.8 & $(0.944)$ \\
B. J. & M & 19 & 9.1 & 28 & 20.0 & 7.9 & 15.5 & $(0.991)$ \\
C. C. & M & 21 & 8.3 & 26 & - & 1.8 & 9.4 & $(0.998)$ \\
R. N. & M & 47 & 9.7 & 29 & 17.4 & 2.5 & 16.8 & $(0.992)$ \\
J. N. & M & 51 & 9.2 & 28 & 15.2 & 3.6 & 15.7 & $(0.977)$ \\
W. H. & M & 41 & 8.5 & 26 & - & 7.8 & 20.0 & $(0.951)$ \\
T. J. & M & 21 & 9.6 & 30 & 18.7 & 4.8 & 8.6 & $(0.994)$ \\
J. J. & M & 18 & 6.8 & 21 & 12.4 & 3.2 & 11.7 & $(0.995)$ \\
P. C. & F & 20 & 5.8 & 18 & - & 5.1 & 18.2 & $(0.988)$ \\
B. P. & M & 14 & 7.8 & 24 & 26.2 & 3.0 & 10.0 & $(0.981)$ \\
K. L. & M & 21 & 9.6 & 30 & 23.6 & 4.2 & 11.4 & $(0.968)$ \\
R. S. & M & 30 & 8.4 & 27 & 17.6 & 1.1 & 11.1 & $(0.988)$ \\
A. W. & F & 23 & 8.6 & 25 & 14.5 & 4.1 & 13.7 & $(0.978)$ \\
& & & & & & & Average & $15.3 \pm 6.3$ (SD) \\
\hline
\end{tabular}

* Mean life-span (see Methods). The numbers in parentheses are the correlation coefficients $(r)$ for the least-squares regression of the log of the radioactivity on time (see Results).

$\ddagger$ This patient had gross splenomegaly.

their untreated red cells. The range is very similar to that reported by $\mathrm{McCurdy}$ for patients with homozygous sickle cell anemia (8). The average MLS was $15.3 \pm 6.3$ days.

Degree of carbamylation. In pilot experiments, treatment of packed red cells in ACD with 0.01, 0.02, and $0.03 \mathrm{M} \mathrm{NCO}$ for $2 \mathrm{~h}$ resulted in the incorporation of approximately $1,1.6$, and $2 \mathrm{~mol} \mathrm{NCO} / \mathrm{mol} \mathrm{Hb}$ respectively, measured chemically as $\mathrm{N}$-terminal carbamylation. Total carbamylation, as measured by incorporation of $\left[{ }^{14} \mathrm{C}\right]$ cyanate into lysed cells, was somewhat higher and gave values of approximately 1.5, 2.8, and $4.0 \mathrm{NCO} / \mathrm{Hb}$ respectively. These results are in good agreement with the findings of other workers (4), and the discrepancy between the results measured

TABLE II

Comparison of Life-Span of Red Cells Treated with $0.02 \mathrm{M}$ NCO and Labeled with both $\left[{ }^{14} \mathrm{C}\right] N C O$ and $\left[{ }^{3} H\right] D F P$ and Studied for 26 days

\begin{tabular}{ccc}
\hline Isotope & \multicolumn{2}{c}{ MLS } \\
\hline$\left.{ }^{3} \mathrm{H}\right] \mathrm{DFP}$ & days & $\left(0 .{ }^{r}\right.$ \\
{$\left[{ }^{14} \mathrm{C}\right] \mathrm{NCO}$} & 17.9 & $(0.945)$ \\
\hline
\end{tabular}

by the two methods presumably is explained by carbamylation of $\xi$-amino groups of hemoglobin and other proteins in the cell, which occurs under these conditions but is not measured in the first method (3). Red cells exposed to solutions of $0.01,0.02$, and $0.03 \mathrm{M} \mathrm{CP}$ had slightly lower levels of $\mathrm{N}$-terminal carbamylation, viz., $0.6,1.1$, and $1.7 \mathrm{NCO} / \mathrm{Hb}$, respectively; thus the degree of carbamylation with either reagent appeared to be linearly proportional to the concentration.

Binding of cyanate to red cells. In one patient, cells were incubated with cyanate $0.02 \mathrm{M}$, containing some $\left[{ }^{14} \mathrm{C}\right] \mathrm{KNCO}$, and also labeled with $\left[{ }^{3} \mathrm{H}\right] \mathrm{DFP}$. The

TABLE III

Comparison of Life-Span of Cells Labeled In Vivo and In Vitro

\begin{tabular}{|c|c|c|c|c|c|}
\hline \multirow[t]{2}{*}{ Patient } & & \multirow[t]{2}{*}{ Isotope } & \multicolumn{2}{|c|}{ MLS } & $\begin{array}{c}\text { No. of } \\
\text { days } \\
\text { followed }\end{array}$ \\
\hline & & & days & $r$ & \\
\hline W. H. & $\begin{array}{l}\text { In vivo } \\
\text { In vitro }\end{array}$ & $\begin{array}{l}\left.{ }^{22} \mathrm{P}\right] D F P \\
{\left[{ }^{3} \mathrm{H}\right] D F P}\end{array}$ & $\begin{array}{l}20.0 \\
25.0\end{array}$ & $\begin{array}{l}(0.951) \\
(0.976)\end{array}$ & $\begin{array}{l}23 \\
60\end{array}$ \\
\hline J. N. & $\begin{array}{l}\text { In vivo } \\
\text { In vitro }\end{array}$ & $\begin{array}{l}\left.{ }^{32} \mathrm{P}\right] \mathrm{DFP} \\
\left.{ }^{3} \mathrm{H}\right] \mathrm{DFP}\end{array}$ & $\begin{array}{l}15.7 \\
16.9\end{array}$ & $\begin{array}{c}(0.977) \\
(0.976)\end{array}$ & $\begin{array}{c}25 \\
36\end{array}$ \\
\hline
\end{tabular}



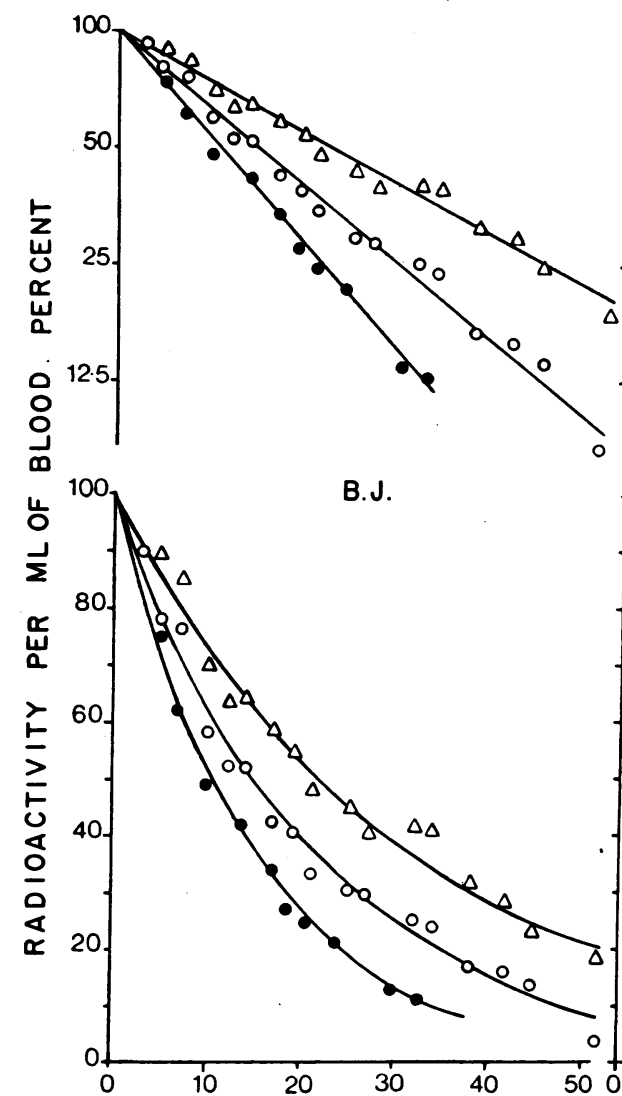

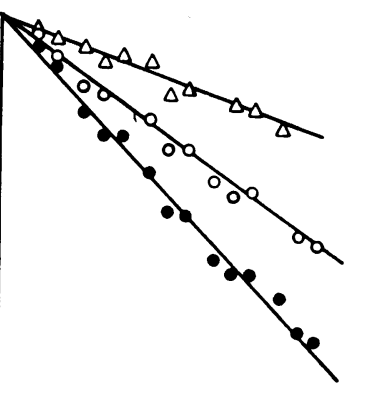

R.N.

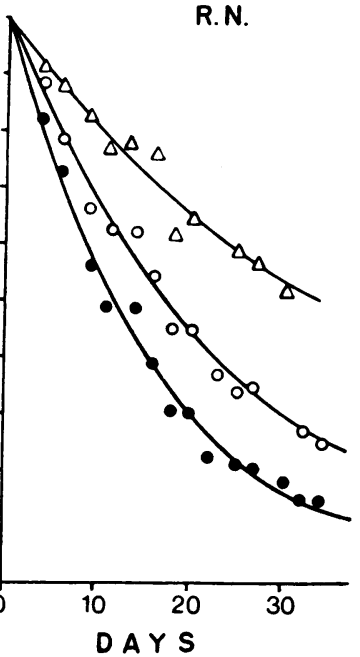

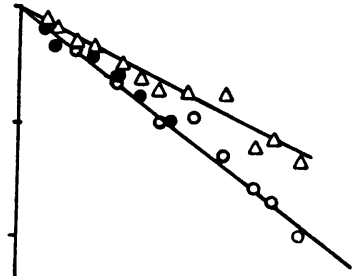

D.P.

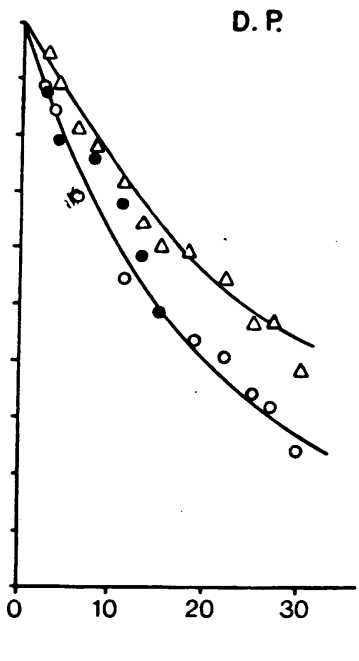

FIGURE 2 Effect of different degrees of carbamylation on $\mathrm{Hb}$ SS red cell survival. Solid circles represent the disappearance of untreated cells; open circles indicate cells treated with $0.01 \mathrm{M}$ reagents; open triangles indicate cells treated with $0.03 \mathrm{M}$ reagents. Red cells from B. J. were treated with $C P$, and cells from D. P. and R. N. were treated with NCO.

results of this rather crude experiment (Table II) showed no appreciable difference in the disappearance of the two labels over this short survival period suggesting, as has been shown by de Furia, Graziano, and Cerami (20) in monkeys and dogs, and by Landaw (21) in rats, that cyanate is irreversibly bound in the red cell.

Comparison of in vivo and in vitro labeling. In most studies untreated red cells were labeled in vivo by direct intravenous injection of DFP, but in all the treated-cell studies, cells were labeled and manipulated in vitro. To see what effect, if any, this manipulation had on subsequent survival, untreated cells were labeled in two patients by both methods, and the survivals were compared simultaneously using two different isotopes. The results, shown in Table III, indicate that cells labeled in vitro had a slightly better survival, presumably because some short-lived cells were either removed during the manipulations and washings or rapidly removed in vivo during the first few days before samples were taken. As the difference was small compared with the difference between treated and untreated red cell survival in most of the studies, we feel justified in claiming that it contributed little to this difference.

Effect of different levels of carbamylation in the same patient. The survival of red cells treated with different concentrations of NCO or CP was compared in three patients (Fig. 2). In each instance the more heavily carbamylated cells survived longer. It was apparent, however, when considering the results of all the experiments, that $0.01 \mathrm{M} \mathrm{NCO}$ was as effective in some patients as $0.03 \mathrm{M} \mathrm{NCO}$ was in others (Table IV). Since degree of deoxygenation was not controlled in these experiments and since DPG binding may affect carbamylation (22), blood from one patient was divided into two portions. One bag was oxygenated and incubated in a shaking water bath with gentle continuous mixing during the $2 \mathrm{~h}$ incubation while the other bag, at venous oxygen saturation, was mixed only once. One 
TABLE IV

Increase in Mean Life-span (MLS) of Carbamylated Red Cells

\begin{tabular}{|c|c|c|c|c|c|}
\hline Patient & $\begin{array}{c}\text { MLS } \\
\text { Untreated } \\
\text { cells }\end{array}$ & & $\begin{array}{l}\text { MLS } \\
\text { Treated } \\
\text { cells }\end{array}$ & $\begin{array}{l}\text { No. of days } \\
\text { survival } \\
\text { followed }\end{array}$ & $\begin{array}{l}\text { Increase } \\
\text { in MLS }\end{array}$ \\
\hline & days & days & $r$ & & days \\
\hline \multicolumn{6}{|c|}{$0.01 \mathrm{M} \mathrm{NCO}$} \\
\hline D. P. & 23.5 & 23.5 & $(0.983)$ & 30 & 0.0 \\
\hline D. R. & 12.8 & 22.5 & $(0.950)$ & 35 & 9.6 \\
\hline C. C. & 9.4 & 22.7 & $(0.976)$ & 35 & 13.0 \\
\hline R. N. & 16.8 & 24.8 & $(0.991)$ & 34 & 8.0 \\
\hline \multirow[t]{2}{*}{ K. L. } & 11.4 & 21.1 & $(0.999)$ & 42 & 9.8 \\
\hline & & & & Average & $\begin{array}{l}8.14 \pm 4.9(\mathrm{SD}) \\
(t=3.7, P=0.02)\end{array}$ \\
\hline \multicolumn{6}{|c|}{$0.02 \mathrm{M} \mathrm{NCO}$} \\
\hline J. J. & 11.7 & 28.9 & $(0.994)$ & 35 & 17.2 \\
\hline P. C. & 18.2 & 27.8 & $(0.988)$ & 54 & 9.6 \\
\hline R. S. & 11.2 & 29.8 & $(0.997)$ & 36 & 18.6 \\
\hline \multirow[t]{2}{*}{ A. W. } & 13.7 & 27.0 & $(0.990)$ & 59 & 13.3 \\
\hline & & & & Average & $\begin{array}{l}14.7 \pm 4.1(\mathrm{SD}) \\
(t=7.2, P=<0.01)\end{array}$ \\
\hline \multicolumn{6}{|c|}{$0.03 \mathrm{M} \mathrm{NCO}$} \\
\hline W. M. & 13.8 & 29.6 & $(0.978)$ & 35 & 15.8 \\
\hline E. G. & 15.8 & 45.2 & $(0.967)$ & 33 & 29.4 \\
\hline G. D. & 34.9 & 42.4 & $(0.968)$ & 34 & 7.4 \\
\hline D. P. & 23.4 & 34.0 & $(0.968)$ & 30 & 10.6 \\
\hline R. N. & 16.8 & 46.3 & $(0.979)$ & 30 & 29.5 \\
\hline J. N. & 15.7 & 37.6 & $(0.986)$ & 36 & 21.9 \\
\hline \multirow[t]{2}{*}{ W. H. } & 20.0 & 34.2 & $(0.996)$ & 60 & 14.2 \\
\hline & & & & Average & $\begin{array}{l}18.4 \pm 8.8(\mathrm{SD}) \\
(t=5.5, P=<0.01)\end{array}$ \\
\hline \multicolumn{6}{|c|}{$0.03 \mathrm{M} \mathrm{CP}$} \\
\hline A. I. & 18.8 & 58.4 & $(0.941)$ & 32 & 39.5 \\
\hline R. W. & 18.9 & 55.4 & $(0.984)$ & 33 & 36.5 \\
\hline S. R. & 6.7 & 29.4 & (0.991) & 36 & 22.6 \\
\hline \multirow[t]{2}{*}{ B. J. } & 15.5 & 32.3 & (0.991) & 52 & 16.8 \\
\hline & & & & Average & $\begin{array}{l}28.9 \pm 11.0(\mathrm{SD}) \\
(t=5.3, P=<0.01)\end{array}$ \\
\hline
\end{tabular}

bag was labeled with $\left[{ }^{14} \mathrm{C}\right] \mathrm{DFP}$ and the other with $\left[{ }^{3} \mathrm{H}\right] \mathrm{DFP}$. The MLS of these red cells were 31.4 and 32.2 days, respectively. We interpret this as indicating that sizeable errors were not introduced by variable degrees of oxygenation of the venous blood.

Comparison of carbamylation with $N C O$ and $C P$ at the same concentration. In six patients one lot of red cells was treated with cyanate, another lot was treated with carbamyl phosphate, and their survival was followed simultaneously with that of untreated cells (Fig. 3). The consistently longer survival of cells exposed to NCO was concordant with the results of carbamylation measurements in the pilot experiments mentioned above and again suggested that increase in survival was determined by degree of carbamylation. In four other patients whose cells were followed after exposure to $0.03 \mathrm{M} \mathrm{CP}$, two showed a remarkable increase in survival (Table IV). As we did not have carbamylation measurements on these samples we cannot explain these results at present.

Degree of improvement in the MLS after carbamylation. Exposure of $\mathrm{Hb} \mathrm{SS}$ red cells to cyanate (Table IV) at a concentration of $0.01 \mathrm{M}$ produced a significant increase in their MLS (8.14 \pm 4.9 days.). After exposure to $0.03 \mathrm{M} \mathrm{NCO}$, the increase in MLS ranged from 7.4 to 29.5 days with a mean of 18.4 days. The dis- 


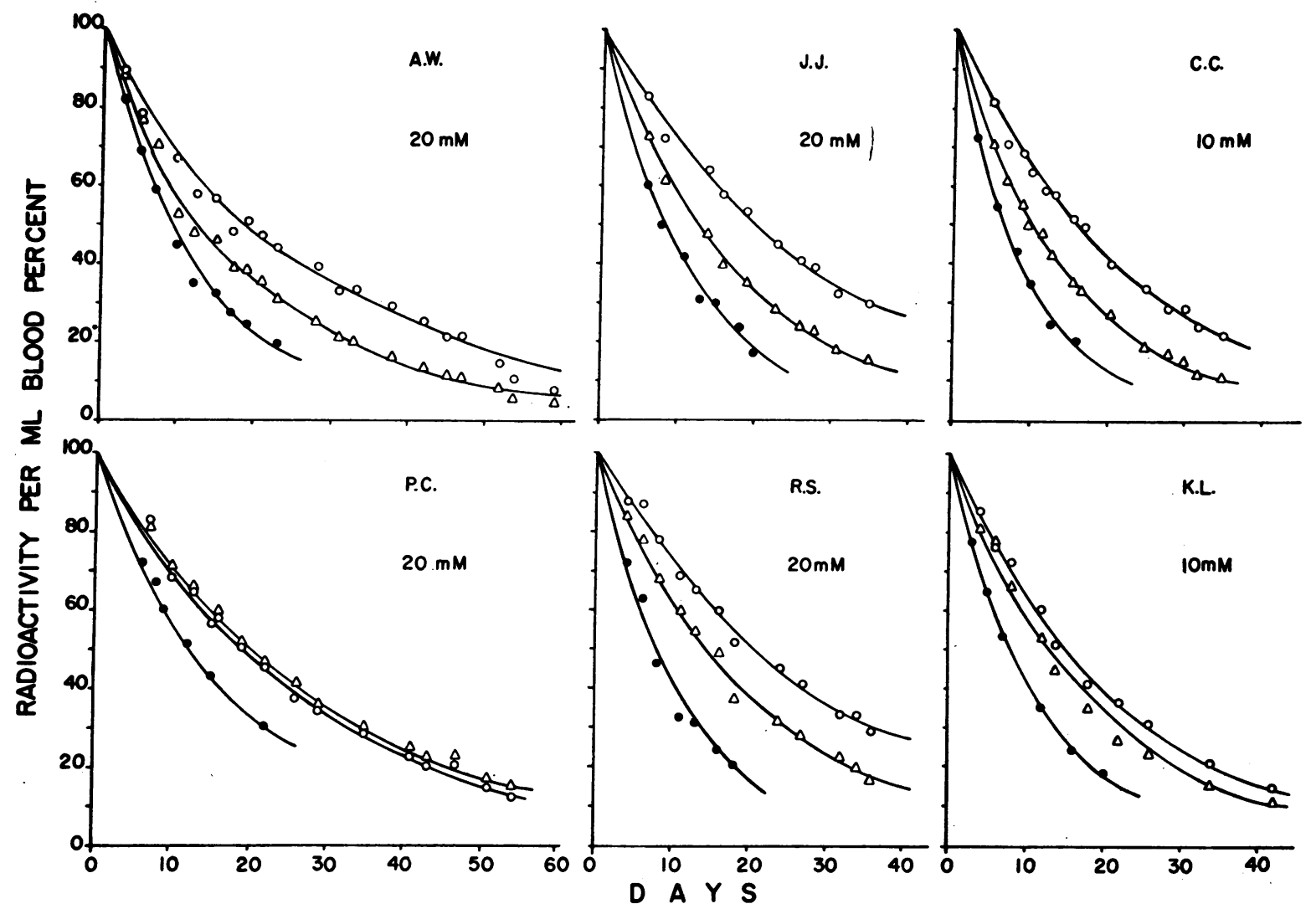

FIGURE 3 Effect on $\mathrm{Hb}$ SS red cell survival of carbamylation with NCO (open circles) and CP (open triangles). The untreated cells are indicated by solid circles. At equimolar concentration in the incubation mixture, NCO is more effective $(t=3.33, P=<0.02)$.

appearance curve was still an exponential after carbamylation in every case, which could mean that a random type of destruction was still operating although at a lesser rate. In two patients, cells treated with $0.03 \mathrm{M} \mathrm{CP}$ had a mean life-span of 58.4 and 55.4 days, respectively. Unfortunately it was impractical to continue sampling beyond 40 days in these two cases, but if the steady rate of random destruction is extrapolated out, for example in patient A.I. (Fig. 4), there would apparently be $12 \%$ of the originally labeled cells still present in the circulation at 120 days, at which point presumably the survival curve would subside to the time axis. The reticulocyte counts in this patient at the time of labeling was $17 \%$. This suggests that some of the cells that were only a few days old at the time of carbamylation might survive for a normal life span, i.e., they would escape the sickling process. The only other event that would affect the rate of destruction would be the onset of premature senescence. If this occurred, possibly due to the effect of carbamylation on the metabolism of the red cells $(23,24)$, the function would subside to the time axis before 124 days. In patient W. H., whose red cells, carbamylated with $0.03 \mathrm{M} \mathrm{NCO}$, were followed for 60 days (Table IV), $17 \%$ of the cells were still present at this time on an exponential curve. A longer observation period of the survival of carbamylated, and preferably normal, red cells would be necessary to prove that premature senescence occurs.

The effect of any particular concentration of carbamylating agent was somewhat unpredictable, survival times being better after exposure to $0.01 \mathrm{M} \mathrm{NCO}$ in some patients than after exposure to $0.03 \mathrm{M} \mathrm{NCO}$ in others. Although we consider it an improbable explanation, for reasons given above, degrees of carbamylation may have varied in these samples. It was noted, however, that on the whole patients with the shortest survival of untreated cells had the greatest increase after carbamylation (Table IV). Similarly, patients with a milder rate of destruction showed little increase after carbamylation, for example G. D. whose red cell MLS was 35 days and increased to only 42.4 days after carbanylation with $0.03 \mathrm{M}$ NCO. For cells treated with $0.03 \mathrm{M}$ NCO there was also a positive correlation 


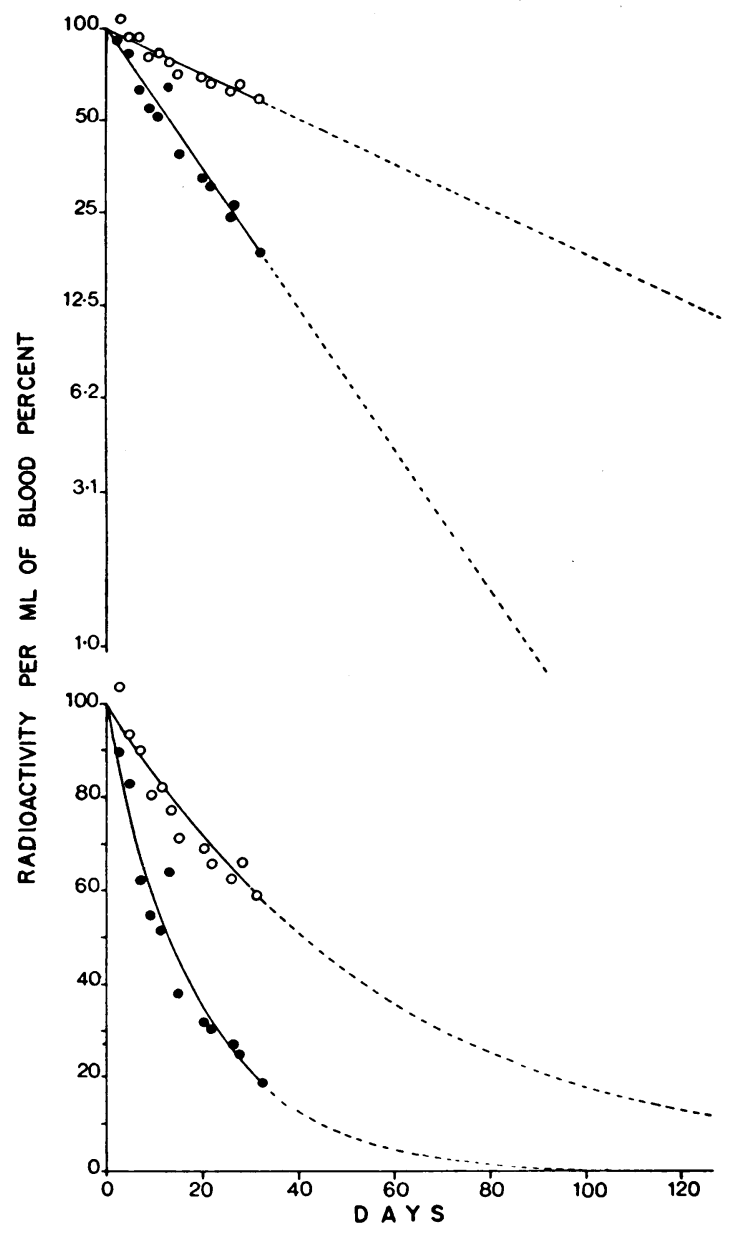

FIGURE 4 Effect of carbamylation with $0.03 \mathrm{M} \mathrm{CP}$ on red cell survival in patient $A$. I. At the top the data are plotted on a logarithmic ordinate and below on a linear ordinate. The initial rates of disappearance of the labeled cells have been extrapolated (broken lines) to show that, if the function for the carbamylated cells (open circles) continued at the same rate, $12 \%$ of those cells would still be present at 120 days.

between increase in MLS and reticulocyte count ( $r=$ $0.7414, P=<0.05)$. If red cell destruction in $\mathrm{Hb} \mathrm{SS}$ is determined by an accumulation of lesions produced by the effects of the sickle-unsickle cycle (25), it seems possible that red cells might benefit more from carbamylation at an early age than later on in their life span. If so, the younger the mean cell age of the red cell population treated, the greater would be the effect of protecting them from sickling.

Effect of carbamylation on the survival of young cells. To test the above hypothesis we took a unit of blood from one patient and centrifuged it to concentrate the less dense and younger cells in the upper portion of the red cell mass. By placing a Peyer surgical clamp across the bag it was possible to separate these red cells. Half the low-density population of cells was carbamylated with $0.03 \mathrm{M} \mathrm{NCO}$ and labeled with DFP. The other half was labeled with a second isotope, and the circulating red cell population was labeled in vivo with a third isotope of DFP. Decay curves of all three isotopes of DFP were then followed. The result is shown graphically in Fig. 5. Unfortunately, the patient developed an intercurrent infection and painful crisis about the 30th day of the survival study, and a steady state with regard to his red cell mass was probably not maintained, since reticulocyte counts and hematocrit both fell. Up to this point, however, the carbamylated, separated population had a greatly decreased rate of removal when compared with the uncarbamylated, but separated, population. The MLS of circulating cells labeled in vivo was only 8.6 days. Extrapolation of the disappearance rate of the uncarbamylated, lowdensity, population shows that less than $0.1 \%$ would survive to 124 days whereas, if the carbamylated cells continued to disappear at the rate measured over the first 30 days, $20 \%$ would survive to the normal life span. This is an exaggeration of the effect already noted and confirms that carbamylation has a more pronounced effect on the rate of hemolysis when the cell population has been manipulated to remove the denser, and probably older and already damaged, red cells. The fact that data for the separated, carbamylated population fit a fairly good line on linear coordinates when the last two points are included is probably fortuitous and illustrates the uncertainty in analyzing these curves. As the last two points are probably invalid, no conclusion can be reached. The same patient, who has been taking oral cyanate $(28 \mathrm{mg} / \mathrm{kg}$ body weight) daily for $3 \mathrm{mo}$, and whose hemoglobin is carbamylated to the extent of $0.5 \mathrm{~mol} \mathrm{NCO} / \mathrm{mol} \mathrm{Hb}$, now has a red cell mean life span of 18 days (Fig. 5, insert).

Distribution of $\left[{ }^{14} \mathrm{C}\right] \mathrm{NCO}$ among a red cell population after carbamylation in vivo. In one patient a single dose of $300 \mathrm{mg}$ of sodium cyanate, containing $50 \mu \mathrm{Ci}\left[{ }^{14} \mathrm{C}\right] \mathrm{KNCO}$, was given orally, and the blood was sampled after $24 \mathrm{~h}$. The hematocrit was adjusted to approximately $50 \%$ and the cells were fully oxygenated. They were then centrifuged in a cellulose nitrate tube at $140,000 \mathrm{~g}$ for half an $\mathrm{h}$ by a previously described technique (26) and the packed-cell column cut with a tube slicer into a top, middle, and bottom fraction. The ${ }^{14} \mathrm{C}$ specific activity of hemoglobin in the washed lysed cells from each fraction was measured. The results given in Table $\mathrm{V}$ show that specific activity was the same throughout the red cell population, suggesting that the degree of carbamylation is not dependent on cell age. 


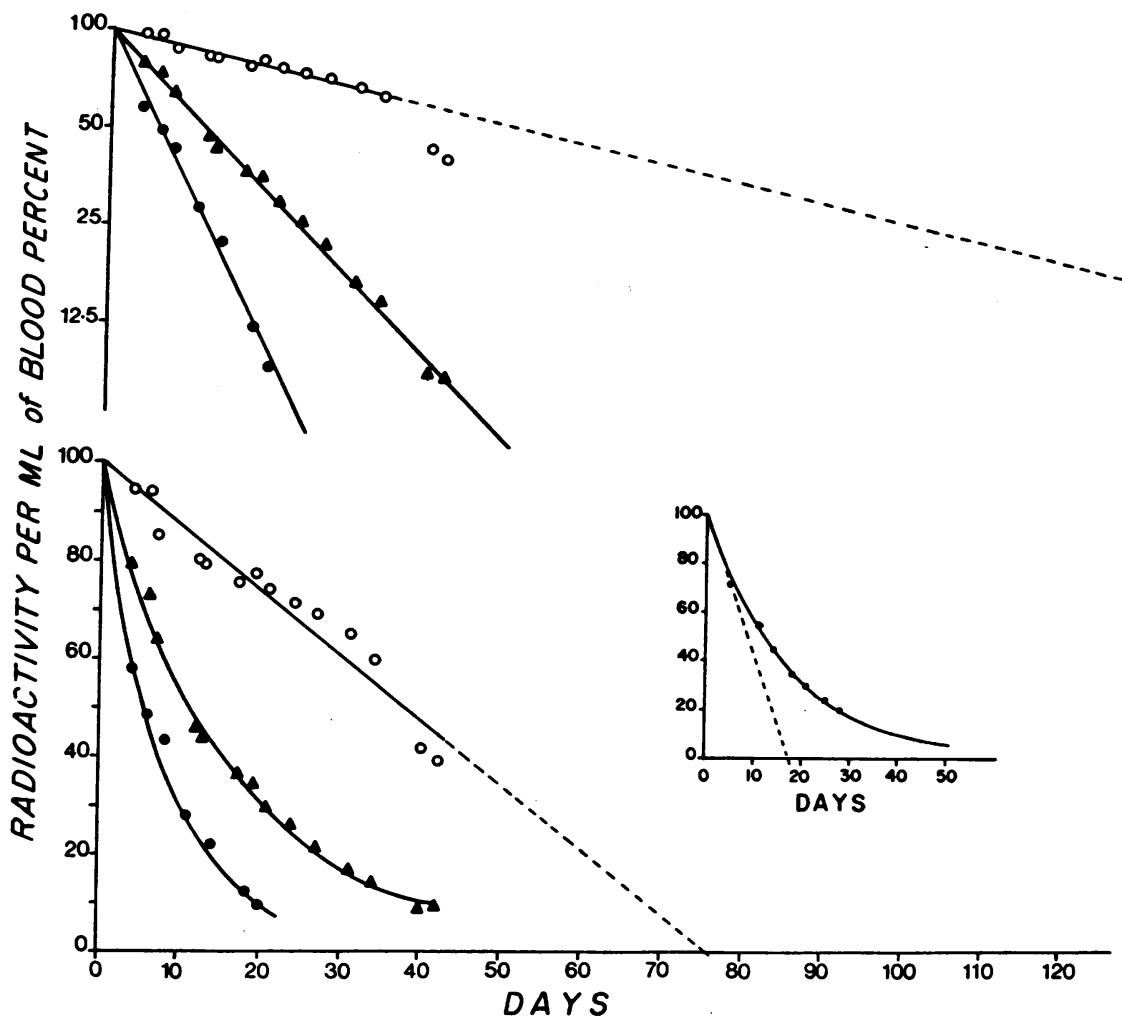

FIGURE 5 Survival, in vivo, of low-density $\mathrm{Hb}$ SS red cells separated by centrifugation (see text) and carbamylated (open circles) compared with the same separated red cells not carbamylated (solid triangles). The regression of $\log \mathrm{dpm}$ (shown as percent radioactivity) is indicated at the top, but the last two points for carbamylated cells have been excluded from the calculations. At the bottom the data are shown on a linear ordinate and, for the carbamylated cells (open circles), the linear regression has been calculated including the last two points. The concurrent survival of the circulating red cells, labeled in vivo, is indicated by solid circles. The insert shows the survival of the same patient's red cells, labeled in vivo, after 3 mo of carbamylation by oral cyanate (see text).

\section{DISCUSSION}

Our results confirm the findings of Gillette and coworkers (2) that carbamylation of $\mathrm{Hb}$ SS red cells improves their in vivo survival. If a method were to be developed whereby the whole red cell mass could be carbamylated in a closed system, a temporary decrease in red cell destruction rate would be achieved. In such a system, carbamyl phosphate might be a better agent than cyanate because of the large amounts of carbamyl phosphatase present in tissues, which can decompose carbamyl phosphate to ammonia and $\mathrm{CO}_{2}(27-29)$, thus lessening the need to wash the cells free of cyanate which may be toxic to other tissues. The data presented here, however, suggest that the goals of intermittent extracorporeal carbamylation would be difficult to accomplish.

Even from the appearance of the blood smear in sickle cell anemia it is evident that the red cell population is heterogeneous. In a population of $\mathrm{Hb} \mathrm{SS}$ erythrocytes the hemoglobin concentration varies considerably from cell to cell $(26,30,31)$, as does the content of $\mathrm{Hb} \mathrm{F}(26$, $32)$ and the number of irreversibly sickled cells $(26,31$, 33). The number of irreversibly sickled cells seen in smears is probably an index of the rate at which they are forming (26), and it has been shown to correlate with the rate of destruction (33). A series of sicklingunsickling event are thought to lead to the formation

\section{TABLE V}

Distribution of Specific Activity of $\left[{ }^{14} \mathrm{C}\right] \mathrm{NCO}$ Labeled

Hemoglobin in the Red Cell Population, $24 \mathrm{~h}$ after Ingestion of a Single Dose of ${ }^{14} \mathrm{C}$-Labeled Cyanate (see text)

\begin{tabular}{llc}
\hline & Fraction & $\mathrm{dpm} / \mathrm{g} \mathrm{Hb}$ \\
\hline Top & 4615 \\
Middle & 4359 \\
Bottom & 4797 \\
\hline
\end{tabular}


of irreversibly sickled cells and their ultimate hemolysis (25) so that, at any given moment, the red cell population in $\mathrm{Hb}$ SS disease consists mainly of variously damaged cells that are destined for early hemolysis, some young cells that have not yet been damaged by sickling, and some older cells that have survived because of a high content of $\mathrm{Hb} \mathrm{F}$ or other attributes inhibitory to sickling. Our studies show that, even at the highest levels of N-terminal carbamylation (about $2 \mathrm{~mol} \mathrm{NCO} / \mathrm{mol}$ $\mathrm{Hb}$ ), although the mean life spans of whole populations were approximately doubled, the treated cells still had only an average MLS of 38.5 days. As noted by Alter, Kan, and Nathan (34), "the most striking effect of carbamylation is the improvement of the survival of the most rapidly destroyed population, suggesting that the development of irreversibly sickled cells may be inhibited by this agent." Our results confirm this; carbamylation has a more pronounced effect on the survival of the youngest cells. It is also evident, however, that carbamylation of these cells did not entirely prevent them from sickling in vivo. The results of in vivo experiments with carbamylated reticulocytes (34) tend to confirm this interpretation. This is in keeping with in vitro studies $(1,6,35)$ which have shown that sickling is inhibited only to the extent to which the oxygen dissociation curve is shifted to the left. $\mathrm{Hb} \mathrm{SS}$ cells exposed to $0.01 \mathrm{M} \mathrm{NCO}$ for $2 \mathrm{~h}$ still sickle on exposure to moderate hypoxia $(1,6,35)$, to the extent of some $50 \%$ of the cells.

Daily oral therapy with sodium cyanate, at a dose level of $30 \mathrm{mg} / \mathrm{kg}$ body weight, gradually carbamylates the circulating hemoglobin to a maximum of about 0.5 $\mathrm{mol} \mathrm{NCO} / \mathrm{mol} \mathrm{Hb}$ (36). Even if a blood level of $1 \mathrm{~mol}$ $\mathrm{NCO} / \mathrm{mol} \mathrm{Hb}$ could be maintained without toxicity, it does not follow that all the circulating cells will be carbamylated to the same extent, but rather that cells which have been circulating for a day or two will have less carbamylation than cells which have been circulating for several weeks. The rate at which newly formed cells become carbamylated to an extent that will protect them from sickling, before they are fatally damaged by sickling, may determine the extent by which the red cell survival can be improved. From the results of our studies it does not seem that carbamylation to the extent of 1 mol $\mathrm{NCO} / \mathrm{mol} \mathrm{Hb}$ will have more than a modest effect on red cell survival, although we cannot predict the increase in red cell survival which would be produced by oral therapy to this mean level of carbamylation. Certainly the hemolytic anemia will not be cured, and we must await further clinical evaluation of this new therapeutic agent to see whether some decrease in the rate of red cell destruction will be accompanied by improvement in the life of the patient.

\section{ACKNOWLEDGMENTS}

We are indebted to Dr. Peter Gillette for measurements of $\mathrm{N}$-terminal carbamylation of hemoglobin samples, to $\mathrm{Dr}$. Nathaniel Berlin for suggesting the use of different isotopes of DFP, and we thank him and Dr. Paul Berk for useful discussions and Miss C. McKesey for technical assistance.

This work was supported by Clinical Research Center Grant RR-35, Grant HL 02799, and Contract 72-2930B from the National Heart and Lung Institute, National Institutes of Health.

\section{REFERENCES}

1. Cerami, A., and J. M. Manning. 1971. Potassium cyanate as an inhibitor of the sickling of erythrocytes in vitro. Proc. Natl. Acad. Sci. U. S. A. 68: 1180.

2. Gillette, P. N., J. M. Manning, and A. Cerami. 1971. Increased survival of sickle-cell erythrocytes after treatment in vitro with sodium cyanate. Proc. Natl. Acad. Sci. U. S. A. 68: 2791.

3. Stark, G. R., W. H. Stein, and S. Moore. 1960. Reactions of the cyanate present in aqueous urea with amino acids and proteins. J. Biol. Chem. 235: 3177.

4. Lee, C. K., and J. M. Manning. 1973. Kinetics of the carbamylation of the amino groups of sickle cell hemoglobin by cyanate. J. Biol. Chem. 248: In press.

5. Kilmartin, J. V., and L. Rossi-Bernardi. 1971. The binding of carbon dioxide by horse haemoglobin. Biochem. J. 124: 31 .

6. Diederich, D. 1972. Relationship between the oxygen affinity and in vitro sickling propensity of carbamylated sickle erythrocytes. Biochem. Biophys. Res. Commun. 46: 1255 .

7. May, A., A. J. Bellingham, E. R. Huehns, and G. H. Beaven. 1972. Effect of cyanate on sickling. Lancet. 1: 658.

8. McCurdy, P. R. 1969. ${ }^{22} \mathrm{DFP}$ and ${ }^{51} \mathrm{Cr}$ for measurement of red cell life span in abnormal hemoglobin syndromes. Blood. J. Hematol. 33: 214.

9. Cline, M. J., and N. I. Berlin. 1963. The red cell chromium elution rate in patients with some hematologic diseases. Blood. J. Hematol. 21: 63

10. Cline, M. J., and N. I. Berlin. 1963. An evaluation of $\mathrm{DFP}^{32}$ and $\mathrm{Cr}^{51}$ as methods of measuring red cell life span in man. Blood. J. Hematol. 22: 459.

11. Cline, M. J., and N. I. Berlin. 1963. Simultaneous measurement of the survival of two populations of erythrocytes with the use of labeled diisopropylflurophosphate. J. Lab. Clin. Med. $61: 249$.

12. Kraus, L. M., and A. P. Kraus. 1971. Carbamyl phosphate mediated inhibition of the sickling of erythrocytes in vitro. Biochem. Biophys. Res. Commun. 44: 1381.

13. Kraus, L. M., A. Rasad, and A. P. Kraus. 1972. Carbamyl phosphate modification of hemoglobin S structure resulting in altered sickling. In Hemoglobin and Red Cell Structure and Function. G. J. Brewer, editor. Plenum Publishing Corporation, New York. 279.

14. International Committee for Standardization in Hematology. 1972. Recommended methods for radioisotopic erythrocyte survival studies. Am. J. Clin. Pathol. 58: 71.

15. Eadie, G. S., and I. W. Brown. 1953. Red blood cell survival studies. Blood. J. Hematol. 8: 1110. 
16. Dornhorst, A. C. 1951. The interpretation of red cell survival curves. Blood J. Hematol. 6: 1284.

17. Eernisse, J. G., and J. J. van Rood. 1961. Erythrocyte survival-time determinations with the aid of $\mathrm{DF}^{22} \mathrm{P}$. Br. J. Haematol. $7: 382$.

18. Garby, L. 1962. Analysis of red-cell survival curves in clinical practice and the use of di-iso-propylfluorophosphonate $\left(\mathrm{DF}^{32} \mathrm{P}\right)$ as a label for red cells in man. Br. J. Haematol. 8 : 15.

19. Manning, J. M., C. K. Lee, A. Cerami, and P. N. Gillette. 1973. Gas chromatographic determination of the carbamylation of hemoglobin S by cyanate. J. Lab. Clin. Med. $81: 941$.

20. de Furia, F. G., J. H. Graziano, and A. Cerami. 1972. Cyanate- ${ }^{14} \mathrm{C}$ : a new method for red cell survivals. J. Clin. Invest. 51 : 24a. (Abstr.)

21. Landaw, S. A. 1973. The use of ${ }^{14} \mathrm{C}$-cyanate for red blood cell survival studies. Proc. Soc. Exp. Biol. Med. $142: 712$.

22. Jensen, M, H. F. Bunn, and D. Nathan. 1973. Carbamylation of hemoglobin $(\mathrm{Hb})$ with cyanate (CNO)-an oxygen linked function. Clin. Res. $21: 558$.

23. Glader, B. S., and M. E. Conrad. 1972. Cyanate inhibition of erythrocyte glucose-6-phosphate dehydrogenase. Nature (Lond.). 237 : 336.

24. de Furia, F. G., D. R. Miller, A. Cerami, and J. M. Manning. 1972. The effect of cyanate in vitro on red blood cell metabolism and function in sickle cell anemia. J. Clin. Invest. $51: 566$.

25. F. Padilla, P. A. Bromberg, and W. N. Jensen. 1973 The sickle-unsickle cycle: a cause of cell fragmentation leading to permanently deformed cells. Blood J. Hematol $41: 653$.

26. Bertles, J. F., and P. F. A. Milner. 1968. Irreversibly sickled erythrocytes: a consequence of the heterogeneous distribution of hemoglobin types in sickle-cell anemia. J. Clin. Invest. 47: 1731
27. Diederich, D., and S. Grisolia. 1971. Purification and properties of acylphosphatase from heart muscle. Comparative properties of acyl phosphatase from several sources. Biochim. Biophys. Acta. 227 : 192.

28. Diederich, D., G. Rampoli, and S. Grisolia. 1971. On the mechanism of enzymatic hydrolysis of carbamyl phosphate. Febs. (Fed. Eur. Biochem. Soc.) Lett. 15: 30.

29. Carreras-Barnes, J., D. A. Diederich, and S. Grisolia. 1972. Some comparative aspects of carbamylation of human blood and of hemoglobin with cyanate and carbamyl phosphate. Eur. J. Biochem. 27: 103.

30. Chien, S., S. Usami, and J. F. Bertles. 1970. Abnormal rheology of oxygenated blood in sickle cell anemia. J. Clin. Invest. 49: 623 .

31. Seakins, M., W. N. Gibbs, P. F. Milner, and J F. Bertles. 1973. Erythrocyte Hb-S concentration. An important factor in the low oxygen affinity of blood in sickle cell anemia. J Clin. Invest. 52: 422.

32. Shepard, M. K., D. J. Weatherall, and C. L. Conley. 1962. Semi-quantitative estimation of the distribution of fetal hemoglobin in red cell populations. Bull. Johns Hopkins Hosp. 110: 293.

33. Serjeant, G. R., B. E. Serjeant, and P. F. Milner. 1969. The irreversibly sickled cell; a determinant of haemolysis in sickle cell anaemia. Br. J. Haematol. $17: 527$.

34. Alter, B. P., Y. W. Kan, and D. G. Nathan. 1973. Reticulocyte survival in sickle cell anemia: effect of cyanate. Blood J. Hematol. 40: 733.

35. Jensen, M. C., H. F. Bunn, G. C. Halikas, and D. G. Nathan. 1972. Oxygen affinity independent action of cyanate and 2,3 DPG on sickling. In Hemoglobin and Red Cell Structure and Function. G. J. Brewer, editor. Plenum Publishing Corporation, New York. 297.

36. Peterson, C. M., Y. S. Lu, J. M. Manning, P. N. Gillette, and A. Cerami. 1973. Studies with oral cyanate in sickle-cell disease. J. Clin. Invest. 52: 64a. (Abstr.) 